\title{
Analisis Niat Pembelian Pada Instagram Online Shopping Menggunakan Information Acceptance Model (IACM)
}

\author{
Wahyutama Fitri Hidayat ${ }^{1}$, Rangga Sanjaya ${ }^{2}$, Ali Mustopa ${ }^{3}$ \\ Universitas Bina Sarana Informatika $a^{1,3}$, ARS University ${ }^{2}$ \\ wahyutama.wfh@bsi.ac.id ${ }^{1}$, rangga@ars.ac.id ${ }^{2}$, alimustopa.aop@bsi.ac.id
}

\begin{abstract}
Abstrak - Seiring perkembangan teknologi dan informasi, berdampak juga terhadap media penjualan produk, salah satunya melalui Instagram online shopping. Penelitian ini bertujuan untuk menganalisis pengaruh electronic word of mounth (EWOM) yang terdapat pada kolom komentar Instagram online shopping terhadap niat pembelian menggunakan model Information Acceptance Model (IACM). Metode yang digunakan dalam penelitian ini adalah deskriptif kuantitatif untuk mengetahu hubungan sebab dan akibat variabel IACM terhadap niat pembelian. Populasi pada penelititan ini adalah pengguna Instagram yang pernah melihat promosi produk melalui Instagram. Teknik sampling yang digunakan adalah insidental sampling dengan membagikan kuesioner secara online. Teknik aanalisis data yang digunakan adalah analisis regresi linier berganda. Berdasarkan hasil penelititan dapat disimpulkan bahwa electronic word of mounth yang terdapat pada Instagram online shopping berpengaruh secara parsial signifikan terhadap niat pembelian. Hal tersebut dapat dilihat dari hasil perhitungan seluruh variabel $t$ hitung $\geq 0,191$ dan tingkat signifikansi $<0,05$. Berdasarkan hasil perhitungan koefesien determinasi $\left(\mathrm{R}^{2}\right)$ dapat diketahui besarnya pengaruh terhadap manfaat informasi yaitu kualitas informasi 19,5\%, kredibilitas informasi $41,3 \%$, kebutuhan informasi $13,9 \%$, dan sikap terhadap informasi $28,6 \%$. Hasil dari adopsi informasi dipengaruhi sebesar $11,2 \%$ oleh manfaat informasi. Hasil lain menunjukan sebesar $24,9 \%$ adopsi informasi mempengaruhi niat pembelian. Sedangkan sikap terhadap informasi mempengaruhi sebesar 38,9\% terhadap niat pembelian.
\end{abstract}

Kata Kunci: Niat Pembelian, Instagram Online Shopping, Information Acceptance Model

Abstract - Along with the development of technology and information, it also has an impact on the product sales media, one of which is through Instagram online shopping. The results of the surf show that comments (electronic word of mount) are on Instagram online shopping. This study aims to analyze the effect of the electronic word of month (EWOM) on purchase intentions using the Information Acceptance Model (IACM) model. The method used in this research is descriptive quantitative to find out the cause and effect relationship of IACM variables. The population in this research is Instagram users who have seen product promotions through Instagram. The sampling technique used is incidental sampling by distributing questionnaires online. The data analysis technique used is multiple linear regression analysis. Based on the results of the research, it can be concluded that the electronic word of mount found on Instagram online shopping has a significant partial effect on purchase intention. This can be seen from the results of the calculation of all the $t$ count variables 0.191 and the significance level 0.05. Based on the results of the calculation of the determination coefficient $\left(R^{2}\right)$, the magnitude of the effect on the benefits of information is information quality $19.5 \%$, information credibility $41.3 \%$, information needs $13.9 \%$, and attitudes towards information $28.6 \%$. The results of information adoption are affected by $11.2 \%$ of the benefits of information. Other Its show that $24.9 \%$ of information adoption affects purchase intentions. While attitudes toward information affect $38.9 \%$ of purchase intentions.

Keywords: Purchase Intention, Instagram Online Shopping, Information Acceptance Model

\section{PENDAHULUAN}

Indonesia merupakan salah satu negara yang memiliki kepadatan penduduk yang cukup tinggi di kawasan Asia Tenggara. Data dari Hootsuite dan WeAreSocial.net menyebutkan 150 juta jiwa pengguna internet aktif di Indonesia pada tahun 2018 (Wahyunanda, 2018). Dari jumlah tersebut 55 juta jiwa diantaranya adalah pengguna media sosial Instagram, dimana Indonesia merupakan pengguna Instagram terbesar ke tiga di dunia setelah Negara Amerika Serikat dan Brasil (Wahyunanda, 2018). Pada era revolusi industri saat ini Instagram tidak hanya digunakan untuk sekedar upload foto atau vidio dan saling menimpali komentar, namun pelaku usaha baik sekala kecil menegah maupun atas mulai memanfaatkan Instagram sebagai media promosi usaha maupun produkya. Adanya promosi menggunakan media Instagram merupakan usaha perusahaan yang bertujuan mempengaruhi konsumen baik bersifat aktual maupun konsumen potensial supaya melakukan pembelian produk yang ditawarkan (Iswara, 2016). Hal tersebut dibuktikan dengan bermunculan online shopping yang mempromosikan barang yang dijual melalui Instagram. 
Teknologi informasi yang berkembang perlahan-lahan mulai menggeser perilaku masyarakat salah satunya adalah budaya pembelian secara online dari cara konvensional. Kondisi ini telah mengubah cara industri dan perilaku pengguna yaitu dengan media sosial untuk mendukung komunikasi. Salah satu hal yang dapat membuat pelanggan merasa puas dan akhirnya minat untuk membeli produk, selain kualitas terdapat faktor yang dapat mempengaruhi adalah interaksi antara penjual dan calon konsumen (Kuspriyono \& Nurelasari, 2018). Menurut Park dan Kim dalam (Iswara, 2016) Kualitas informasi diperlukan untuk melakukan bisnis online karena kualitas informasi menentukan terjadinya keputusan pembelian. Hal ini dikarenakan calon konsumen akan menggali informasi lebih banyak baik melalui media promosi yang digunakan, melalui ulasan atau komentar, maupun melalui orang yang telah melakukan transaksi secara online yang biasa disebut electronic word of mounth (EWOM). EWOM merupakan sebuah fenomena dalam dunia komunikasi pemasaran sehingga setiap individu dapat saling bertukar informasi dan pengalaman mengenai hal yang dialami sebelumnya (Retnowati, 2017). Selain itu informasi yang terdapat pada kolom komentar sebagai saluran komunikasi personal menjadi faktor yang paling tinggi untuk mempengaruhi keputusan pembelian (Bataineh, 2015).

Berdasarkan uraian di atas maka tujuan dari penelitian ini adalah untuk menganalisa pegaruh informasi yang terdapat dalam Instagram online shopping terhadap keputusan pembelian (purchase intention) calon konsumen menggunakan IACM (Information Acceptance Model) yang dikemukakan oleh (Erkan \& Evans, 2016) dengan variabel adopsi informasi, manfaat informasi, kualitas informasi, kredibilitas informasi, kebutuhan informasi dan sikap terhadap informasi terhadap keputusan pembelian

\section{METODE PENELITIAN}

Dalam penelitian ini, digunakan metode deskriptif kuantitatif untuk mengatahui hubungan sebab akibat antar variabel bebas dengan variabel terikat yang telah ditentukan. Penulis mengukur Variabel yang terdapat dalam IACM (Information Acception Model) yaitu adopsi informasi, manfaat informasi, kualitas informasi, kredibilitas informasi, kebutuhan informasi dan sikap terhadap informasi terhadap niat pembelian. Pengumpulan data primer yang diperoleh dari kuisioner menggunakan instrumen penelitian berdasarkan kerangka pemikiran menggunakan skala likert 6 poin menggunakan tehnik insidental sampling. Metode pengujian yang bertujuan sebagai penguji hipotesa yang ditetapkan, penulis dalam penelitian ini dianalisis sesuai metode statistik yang digunakan untuk diinterprestasikan.

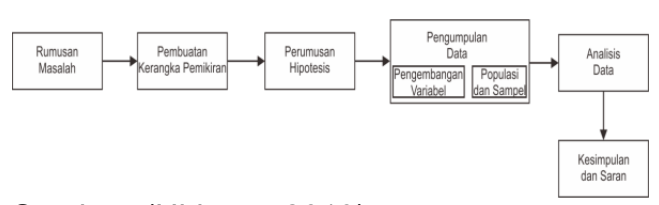

Sumber: (Hidayat, 2019)

Gambar 1. Komponen dan Proses Penelitian

\section{Rumusan Masalah}

Pada tahapan dilakukan penjabaran mengenai malasah yang ditemukan pada kegiatan online shopping yang dilakukan melalui Instagram terutama yang berkaitan dengan adopsi informasi terhadap minat pembelian.

2. Pembuatan Kerangka Pemikiran

Tahap pembuatan kerangka pemikiran didasarkan pada Information Aceptance Model (IACM) yang dikemukakan oleh Erkan dan Evans sehingga diperoleh variabel adopsi informasi, manfaat informasi, kualitas informasi, kredibilitas informasi, kebutuhan informasi dan sikap terhadap informasi.

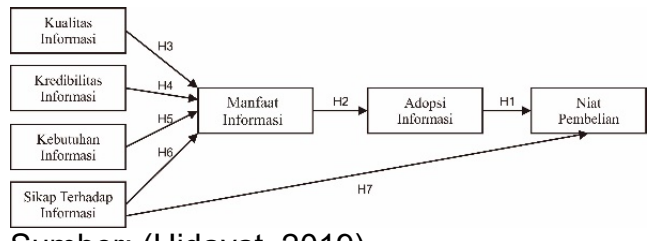

Sumber: (Hidayat, 2019)

Gambar 2. Kerangka Pemikiran

\section{Perumusan Hipotesis}

Dengan menggunakan Information Acceptance Model (IACM) maka hipotesis dapat ditetapkan $\mathrm{H} 1$ sampai dengan $\mathrm{H} 7$ dimana hipotesis yang sudah ditetapkan didasarkan pada hubungan antar variabel.

H1: Adopsi informasi secara positif mempengaruhi terhadap niat pembelian.

H2: Manfaat informasi secara positif mempengaruhi terhadap adopsi informasi.

H3: Kualitas informasi secara positif mempengaruhi terhadap manfaat informasi.

H4: Kredibilitas informasi secara positif mempengaruhi terhadap manfaat informasi.

H5: Kebutuhan informasi secara positif mempengaruhi terhadap manfaat informasi.

H6: Sikap terhadap informasi secara positif mempengaruhi terhadap manfaat informasi.

H7: Sikap terhadap informasi secara positif mempengaruhi terhadap niat pembelian.

4. Pengumpulan Data

Pengembangan variabel bertujuan untuk menjabarkan masing-masing variabel menjadi 
butir-butir pertanyaan. Sehingga dari masingmasing pertanyaan dapat diukur menggunakan skala likert berdasarkan variabel dari Information Acceptance Model (IACM)

Populasi dari penelitian ini merupakan pengguna Instagram yang pernah melakukan pembelian melalui Instagram online shopping. Namun dikarenakan populasi yang cukup besar maka sampel dipilih menggunakan tehnik sampling incidental terhadap kriteria yang sesuai.

\section{Analisis Data}

Metode analisis data dengan menggunakan metode kuantitatif. Dalam pelaksanaan penelitian ini, jenis atau alat penelitian yang digunakan adalah statistik deskriptif, statistik verifikatif, uji asumsi klasik, analisis korelasi, analisis jalur, dan analisis koefisien determinasi menggunakan aplikasi SPSS (Statistical Package for the Social Sciences).

6. Kesimpulan dan Saran

Pada tahapan ini berisi ringkasan dari penelitian, hasil analisis dan pembahasan data, serta menjawab permasalahan penelitian. Selain itu pada tahapan ini juga berisi saran mengenai model penelitian yang digunakan serta aspek yang mempengaruhi niat pembelian secara online.

\section{PEMBAHASAN DAN HASIL}

Pada penelitian ini digunakan data hasil penyebaran kuesioner kepada responden. Dari penyebaran kuesioner ini diperoleh data primer penelitian, dimana sampel dari penelitian ini berjumlah 104 responden, yaitu orang yang mengunakan akun instagramnya untuk melakukan pembelian produk secara online. Karakteristik dari responden yang menggunakan akun Instagramnya untuk melakukan kegiatan online shopping terdapat berbagai macam karakter yang dibedakan berdasarkan jenis kelamin, usia, tingkat pendidikan, status pekerjaan, dan rata-rata uang belanja atau uang saku setiap bulan.

1. Profil Responden

Tabel 1. Berdasarkan Jenis Kelamin

\begin{tabular}{ccc}
\hline Jenis & $\begin{array}{c}\text { Frekuensi } \\
\text { Kelamin }\end{array}$ & $\begin{array}{c}\text { Presentase } \\
\text { (F) }\end{array}$ \\
Laki-laki & 50 & $51,9 \%$ \\
Perempuan & 54 & $48,1 \%$ \\
Total & $\mathbf{1 0 4}$ & $\mathbf{1 0 0 \%}$ \\
\hline Sumber: Google Form bit.ly/IGolshop (2019)
\end{tabular}

diketahui bahwa karakteristik responden berdasarkan jenis kelamin yaitu 54 orang atau $51,9 \%$ adalah perempuan, sedangkan $48,1 \%$ sisanya atau 50 orang adalah laki-laki.
Tabel 2. Berdasarkan Usia

\begin{tabular}{ccc}
$\begin{array}{c}\text { Usia } \\
\text { (Tahun) }\end{array}$ & $\begin{array}{c}\text { Frekuensi } \\
\text { (F) }\end{array}$ & $\begin{array}{c}\text { Persentase } \\
\text { (\%) }\end{array}$ \\
15 s/d 19 & 22 & $21,2 \%$ \\
20 s/d 25 & 66 & $63,5 \%$ \\
$>25$ & 16 & $15,4 \%$ \\
Total & $\mathbf{1 0 4}$ & $\mathbf{1 0 0 \%}$ \\
\hline
\end{tabular}

Sumber: Google Form bit.ly/IGolshop (2019)

diketahui bahwa karakteristik responden berdasarkan usia didominasi oleh kelompok usia diantara 20 sampai dengan 25 tahun yaitu sebanyak 66 orang atau $63,5 \%$. Sedangkan untuk kedua terbanyak yaitu pada kelompok usia 15 sampai dengan 19 tahun.

Tabel 3. Berdasarkan Tingkat Pendidikan

\begin{tabular}{ccc}
$\begin{array}{c}\text { Pendidikan } \\
\text { Terakhir }\end{array}$ & $\begin{array}{c}\text { Frekuensi } \\
\text { (F) }\end{array}$ & $\begin{array}{c}\text { Persentase } \\
\text { (\%) }\end{array}$ \\
SD & 0 & $0 \%$ \\
SMP & 10 & $9,6 \%$ \\
SMA & 55 & $52,9 \%$ \\
D3 & 20 & $19,2 \%$ \\
S1 & 18 & $17,3 \%$ \\
S2 & 1 & $1 \%$ \\
Total & $\mathbf{1 0 4}$ & $\mathbf{1 0 0 \%}$ \\
\hline Sumber:
\end{tabular}

Sumber: Google Form bit.ly/IGolshop (2019)

diketahui bahwa karakteristik responden berdasarkan pendidikan terakhir didominasi oleh kelompok pendidikan SMA yaitu sebanyak 55 orang atau $52,9 \%$.

Tabel 4. Berdasarkan Status Pekerjaan

\begin{tabular}{ccc}
$\begin{array}{c}\text { Status } \\
\text { Pekerjaan }\end{array}$ & $\begin{array}{c}\text { Frekuensi } \\
\text { (F) }\end{array}$ & $\begin{array}{c}\text { Persentase } \\
\text { (\%) }\end{array}$ \\
Pelajarl & 49 & $47,1 \%$ \\
Mahasiswa & & \\
Pegawai & 1 & $1 \%$ \\
$\quad$ Negeri & & \\
Karyawan & 38 & $36,5 \%$ \\
Swasta & & \\
TNI/Polri & 0 & $0 \%$ \\
Wirausaha & 12 & $11,5 \%$ \\
Lainnya & 4 & $3,9 \%$ \\
Total & 104 & $100 \%$ \\
\hline Sumber: Google Form bit.ly/lGolshop $(2019)$
\end{tabular}

diketahui bahwa karakteristik
responden berdasarkan status pekerjaan
didominasi oleh kelompok pelajar atau
mahasiswa yaitu sebanyak $47,1 \%$ atau 49
orang Sedangkan untuk kedua terbanyak yaitu
pada kelompok karyawan swasta.


Tabel 5. Berdasarkan Status Pekerjaan

\begin{tabular}{ccc} 
Uang Saku & $\begin{array}{c}\text { Frekuensi } \\
\text { (F) }\end{array}$ & $\begin{array}{c}\text { Persentase } \\
\text { (\%) }\end{array}$ \\
< Rp.500.000, & 36 & $34,6 \%$ \\
Rp. 500.000, & 41 & $39,4 \%$ \\
s/d Rp. 1 juta & & \\
> Rp. 1 juta & 27 & $26 \%$ \\
Total & $\mathbf{1 0 4}$ & $\mathbf{1 0 0 \%}$ \\
\hline \multicolumn{2}{c}{ Sumber: Google Form bit.ly/IGolshop (2019) }
\end{tabular}

diketahui bahwa karakteristik responden berdasarkan rata-rata uang belanja atau uang saku setiap bulan didominasi oleh kelompok uang belanja atau uang saku sebesar Rp.500.000,- sampai dengan Rp.1 juta yaitu 41 orang atau $39,4 \%$.

2. Hasil Uji Asumsi Klasik

a. Uji Validitas

Uji validitas dilakukan untuk mengukur apakah instrumen penelitian benar-benar mampu mengukur konstruk yang digunakan. Validitas menunjukkan seberapa jauh perbedaan perolehan dengan instrumen pengukuran merefleksikan ketidaksamaan sesungguhnya pada responden yang diteliti.

\begin{tabular}{lcccc}
\multicolumn{5}{c}{ Tabel 6. Hasil Uji Validitas } \\
\hline Variabel & Indi & $\mathrm{r}_{\text {hitung }}$ & $\mathrm{r}_{\text {tabel }}$ & Kesi \\
& kat & & & mpul \\
& or & & & an \\
\hline Kualitas & IQ1 & 0,601 & 0,191 & Valid \\
Informasi & IQ2 & 0,755 & 0,191 & Valid \\
(IQ) & IQ3 & 0,858 & 0,191 & Valid \\
& IQ4 & 0,860 & 0,191 & Valid \\
Kredibilitas & IC1 & 0,752 & 0,191 & Valid \\
Informasi & IC2 & 0,892 & 0,191 & Valid \\
(IC) & IC3 & 0,376 & 0,191 & Valid \\
Kebutuhan & NI1 & 0,512 & 0,191 & Valid \\
Informasi & NI2 & 0,707 & 0,191 & Valid \\
(NI) & & & & \\
Sikap & Al1 & 0,554 & 0,191 & Valid \\
Terhadap & AI2 & 0,617 & 0,191 & Valid \\
Informasi & AI3 & 0,637 & 0,191 & Valid \\
(AI) & & & & \\
Manfaat & IU1 & 0,433 & 0,191 & Valid \\
Informasi & IU2 & 0,454 & 0,191 & Valid \\
(IU) & & & & \\
Adopsi & IA1 & 0,646 & 0,191 & Valid \\
Informasi & IA2 & 0,739 & 0,191 & Valid \\
(IA) & IA3 & 0,759 & 0,191 & Valid \\
& IA4 & 0,758 & 0,191 & Valid \\
Niat & PI1 & 0,872 & 0,191 & Valid \\
Pembelian & PI2 & 0,764 & 0,191 & Valid \\
(PI) & PI3 & 0,695 & 0,191 & Valid \\
\hline \multicolumn{1}{c}{ Sumber: Sumber: (Hidayat, 2019) } \\
& & & &
\end{tabular}

\section{b. Uji Reliabilitas}

Uji reliabilitas bertujuan untuk mengetahui tingkat konsistensi instrumeninstrumen yang digunakan untuk mengukur konsep. Hasil uji reliabilitas dilakukan dengan uji Cronbach's Alpha (a).

Tabel 7. Hasil Uji Reliabilitas

\begin{tabular}{|c|c|c|c|}
\hline Variabel & $\begin{array}{c}\text { Cronbach's } \\
\text { Alpha }\end{array}$ & $\begin{array}{l}\mathrm{N} \text { of } \\
\text { Items }\end{array}$ & Kesimpulan \\
\hline $\begin{array}{l}\text { Kualitas } \\
\text { Informasi } \\
\text { (IQ) }\end{array}$ & 0,929 & 4 & Reliabel \\
\hline $\begin{array}{l}\text { Kredibilitas } \\
\text { Informasi } \\
\text { (IC) }\end{array}$ & 0,694 & 3 & Reliabel \\
\hline $\begin{array}{l}\text { Kebutuhan } \\
\text { Informasi } \\
\text { (NI) }\end{array}$ & 0,626 & 2 & Reliabel \\
\hline $\begin{array}{l}\text { Sikap } \\
\text { Terhadap } \\
\text { Infrmasi } \\
\text { (IA) }\end{array}$ & 0,604 & 3 & Reliabel \\
\hline $\begin{array}{l}\text { Manfaat } \\
\text { Informasi } \\
\text { (IU) }\end{array}$ & 0,861 & 2 & Reliabel \\
\hline $\begin{array}{l}\text { Adopsi } \\
\text { Informasi } \\
\text { (IA) }\end{array}$ & 0,972 & 4 & Reliabel \\
\hline $\begin{array}{l}\text { Niat } \\
\text { Pembelian } \\
(\mathrm{PI})\end{array}$ & 0,868 & 3 & Reliabel \\
\hline
\end{tabular}

c. Uji Asumsi Klasik

1) Uji Normalitas

Pengujian normalitas bertujuan untuk menguji data variabel dalam regresi yang dihasilkan apakah berdistribusi normal atau berdistribusi tidak normal.

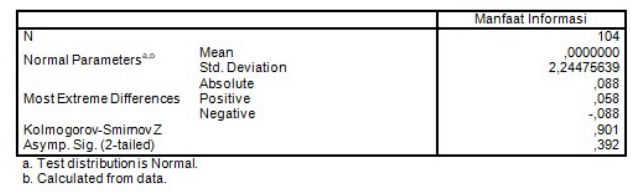

Sumber:(Hidayat, 2019)

Gambar 3. Uji Normalitas IQ,IC,NI,AI Terhadap UI

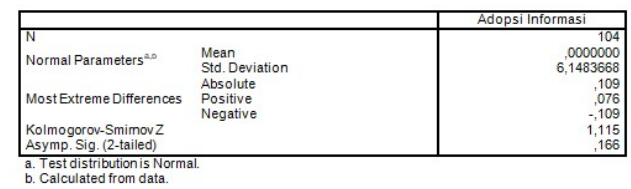

Sumber: (Hidayat, 2019)

Gambar 4. Uji Normalitas IU Terhadap IA

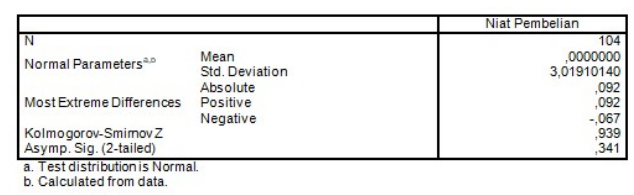

Sumber: (Hidayat, 2019)

Gambar 5. Uji Normalitas IA Terhadap PI 


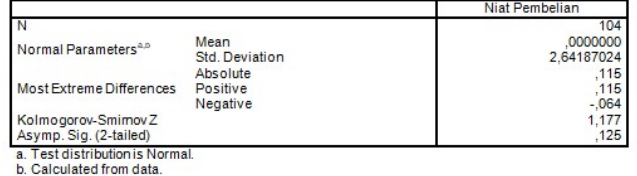

Sumber: (Hidayat, 2019)

Gambar 6. Uji Normalitas AI Terhadap PI

2) Uji Multikolinearitas

Uji multikolinearitas bertujuan untuk mengetahui apakah terjadi interkorelasi (hubungan yang kuat) antar variabel bebas. Model regresi yang baik ditandai dengan tidak terjadi interkorelasi antar variabel bebas (tidak terjadi gejala multikolinearitas).

\begin{tabular}{|c|c|c|c|}
\hline \multirow{2}{*}{\multicolumn{2}{|c|}{ Model }} & \multirow[b]{2}{*}{ Tolerance } & \multirow[b]{2}{*}{ VIF } \\
\hline & & & \\
\hline \multirow{4}{*}{1} & Kualitas Informasi & .445 & 2,245 \\
\hline & Kredibilitas Informasi &, 529 & 1,891 \\
\hline & Kebutuhan Informasi & .402 & 2,486 \\
\hline & Sikap Terhadap Informasi & 328 & 3,047 \\
\hline
\end{tabular}

Sumber: (Hidayat, 2019)

Gambar 7. Uji Multikolinearitas IQ,IC,NI,AI Terhadap UI

\begin{tabular}{|l|r|r|}
\hline \multicolumn{2}{|l|}{ Model } & \multicolumn{2}{|c|}{} \\
\cline { 2 - 3 } & Tolerance & \multicolumn{1}{|c|}{ VIF } \\
\hline $1 \quad$ Manfaat Informasi & 1,000 & 1,000 \\
\hline
\end{tabular}

Sumber: (Hidayat, 2019)

Gambar 8. Multikolinearitas IU Terhadap IA

\begin{tabular}{|l|r|r|}
\hline \multicolumn{2}{|l|}{ Model } & \multicolumn{2}{|c|}{} \\
\cline { 2 - 3 } & Tolerance & \multicolumn{1}{|c|}{ VIF } \\
\hline $1 \quad$ Adopsilnformasi & 1,000 & 1,000 \\
\hline
\end{tabular}

Sumber: (Hidayat, 2019)

Gambar 9. Uji Multikolinearitas IA Terhadap PI

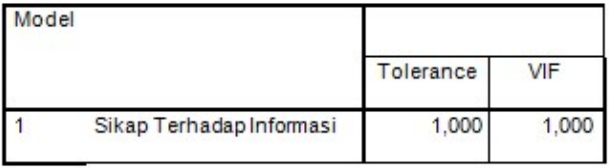

Sumber: (Hidayat, 2019)

Gambar 10. Uji Multikolinearitas IU Terhadap PI

3) Uji Heterokedastisitas

Uji heteroskedastisitas bertujuan menguji apakah kesalahan (errors) pada data kita memiliki varian yang sama atau tidak. Kriteria yang digunakan adalah jika terdapat pola tertentu pada grafik scatter plot. Apabila titik-titik yang ada menyebar diatas dan dibawah angka 0 sumbu maka tidak terjadi heteroskedastisitas.

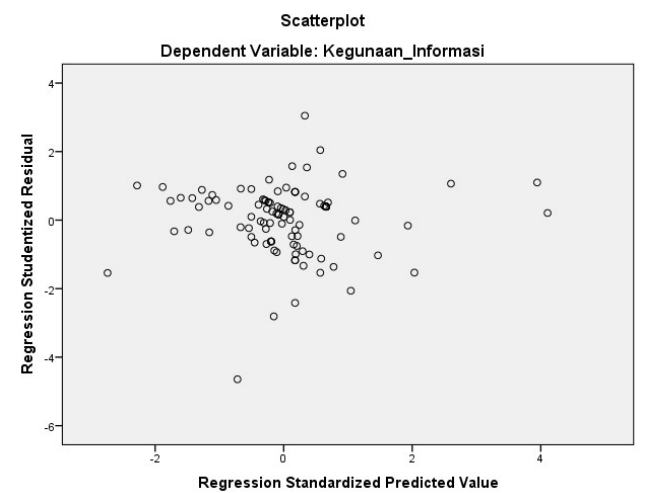

Sumber: Penulis (2019)

Gambar 11. Uji Heteroskedastisitas Terhadap Manfaat Informasi

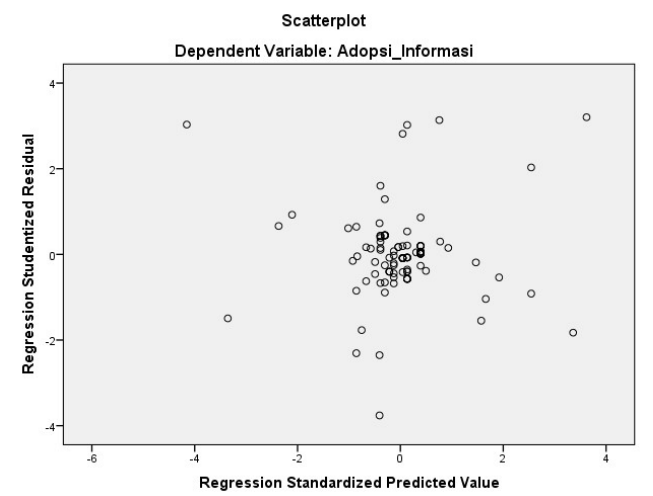

Sumber: (Hidayat, 2019)

Gambar 12. Uji Heteroskedastisitas Terhadap Adopsi Informasi

Scatterplot

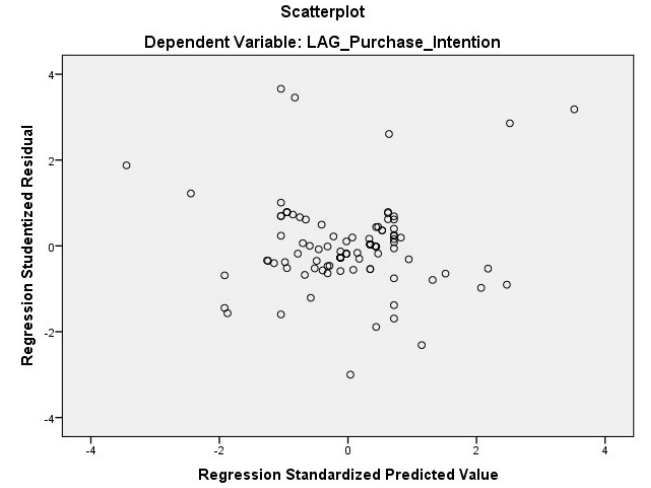

Sumber: (Hidayat, 2019)

Gambar 11. Uji Heteroskedastisitas Terhadap Niat pembelian

3 Hasil Uji Hipotesis

a. Uji Koefesien Determinasi

Koefisien determinasi $\left(R^{2}\right)$ bertujuan untuk mengetahui besarnya sumbangan atau kontribusi dari IACM terhadap Niat Pembelian. Koefisien determinasi berguna untuk menunjukan seberapa besar pengaruh variabel 
bebas memiliki pengaruh terhadap variabel terikatnya.

\begin{tabular}{|l|c|r|r|c|}
\hline Model & $R$ & R Square & $\begin{array}{c}\text { Adjusted R } \\
\text { Square }\end{array}$ & $\begin{array}{c}\text { Std. Error of the } \\
\text { Estimate }\end{array}$ \\
\hline 1 &, $669^{\circ}$ &, 448 &, 426 & 1,24560 \\
\hline
\end{tabular}

a. Predictors: (Constant), Sikap Terhadap Informasi, Kualitas

Informasi, Kebutuhan Informasi, Kredibilitas Informasi

b. Dependent Variable: Manfaat Informasi

Sumber: (Hidayat, 2019)

Gambar 12. Uji Koefesien Determinasi IQ,IC,NI,Al Terhadap IU

nilai $\mathrm{R}$ square menunjukan bahwa besarnya koefisien determinasi adalah 0,448 atau 44,8\% yang berarti bahwa variabel manfaat informasi dipengaruhi oleh variabel kualitas informasi, kredibilitas informasi, kebutuhan informasi, dan sikap terhadap informasi. Sedangkan nilai yang tersisa yaitu sebesar $55,2 \%$ dipengaruhi oleh faktor-faktor lain.

\begin{tabular}{|ll|r|}
\multicolumn{2}{c}{ Correlations } \\
\hline \multirow{3}{*}{ Kualitas Informasi } & Pearson Correlation & Manfaat Infotmasi \\
& Sig. (2-tailed) &, 442 \\
& $\mathrm{~N}$ &, 000 \\
Kredibilitas Informasi & 103 \\
& Pearson Correlation &, 643 \\
& Sig. (2-tailed) & 000 \\
& $\mathrm{~N}$. & 103 \\
Kebutuhan Informasi & Pearson Correlation &, 373 \\
& Sig. (2-tailed) & 1000 \\
& $\mathrm{~N}$. &, 535 \\
Sikap Terhadap Informasi & Pearson Correlation &, 000 \\
& Sig. (2-tailed) & 103 \\
Manfaat Informasi & $\mathrm{N}$ & 1 \\
& Pearson Correlation & 103 \\
\hline
\end{tabular}

Sumber: (Hidayat, 2019)

Gambar 13. Uji Koefesien Korelasi IQ,IC,NI,AI Terhadap IU

Besarnya pengaruh secara parsial antara masing-masing variabel terhadap manfaat informasi dapat dihitung menggunakan perhitungan rumus koefisien determinasi.

a. Kualitas Informasi

$$
\begin{aligned}
\mathrm{Kd} & =r^{2} \times 100 \% \\
& =(0,442)^{2} \times 100 \% \\
& =19,5 \%
\end{aligned}
$$

b. Kredibilitas Informasi

$$
\begin{aligned}
\mathrm{Kd} & =r^{2} \times 100 \% \\
& =(0,643)^{2} \times 100 \% \\
& =41,3 \%
\end{aligned}
$$

c. Kebutuhan Informasi

$$
\begin{aligned}
\mathrm{Kd} & =r^{2} \times 100 \% \\
& =(0,373)^{2} \times 100 \% \\
& =13,9 \%
\end{aligned}
$$

d. Sikap Terhadap Informasi

$$
\begin{aligned}
\mathrm{Kd} & =r^{2} \times 100 \% \\
& =(0,535)^{2} \times 100 \% \\
& =28,6 \%
\end{aligned}
$$

perhitungan koefisien determinasi masingmasing variabel terhadap Manfaat Informasi dapat diketahui bahwa besar pengaruh secara parsial dari masing-masing variabel bebas yaitu kualitas informasi sebesar 19,5\%, kredibilitas informasi sebesar 41,3\%, kebutuhan informasi sebesar $13,9 \%$, dan sikap terhadap informasi sebesar $28,6 \%$.

\begin{tabular}{|l|c|c|c|c|}
\hline Model & $R$ & $R$ Square & $\begin{array}{c}\text { Adjusted R } \\
\text { Square }\end{array}$ & $\begin{array}{c}\text { Std. Error of the } \\
\text { Estimate }\end{array}$ \\
\hline 1 &, $335^{3}$ &, 112 &, 104 & 3,07532 \\
\hline
\end{tabular}
a. Predictors: (Constant), Manfaat Informasi
b. Dependent Variable: Adopsi Informasi

Sumber: (Hidayat, 2019)

Gambar 14. Uji Koefesien Determinasi IU Terhadap IA

pada nilai $\mathrm{R}$ square menunjukan bahwa besarnya koefisien determinasi adalah 0,112 atau $11,2 \%$ yang berarti bahwa variabel Adopsi Informasi dipengaruhi oleh variabel Manfaat Informasi. Sedangkan nilai yang tersisa yaitu sebesar $89,8 \%$ dipengaruhi oleh faktor-faktor lain.

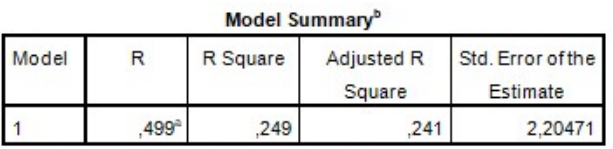

$$
\begin{aligned}
& \text { a. Predictors: (Constant), Adopsi Informasi } \\
& \text { b. Dependent Variable: Purchase Intention }
\end{aligned}
$$

nilai $\mathrm{R}$ square menunjukan bahwa besarnya koefisien determinasi adalah 0,191 atau 24,9\% yang berarti bahwa variabel Niat Pembelian dipengaruhi oleh variabel Adopsi Informasi. Sedangkan nilai yang tersisa yaitu sebesar $75,1 \%$ dipengaruhi oleh faktor-faktor lain.

\begin{tabular}{|l|r|r|r|c|}
\hline Model & $R$ & R Square & $\begin{array}{c}\text { Adjusted R } \\
\text { Square }\end{array}$ & $\begin{array}{c}\text { Std. Error of the } \\
\text { Estimate }\end{array}$ \\
\hline 1 &, $623^{3}$ &, 389 &, 383 & 1,99004 \\
\hline
\end{tabular}
a. Predictors: (Constant), Sikap Terhadap Informasi
b. Dependent Variable: Purchase Intention

Sumber: (Hidayat, 2019)

Gambar 16. Uji Koefesien Determinasi IA Terhadap PI

nilai $\mathrm{R}$ square menunjukan bahwa besarnya koefisien determinasi adalah 0,389 atau 38,9\% yang berarti bahwa variabel Niat Pembelian dipengaruhi Sikap Terhadap Informasi. Sedangkan nilai yang tersisa yaitu sebesar $61,1 \%$ dipengaruhi oleh faktor-faktor lain. hasil perhitungan koefisien determinasi pada model regresi IACM terhadap Niat Pembelian, besar pengaruh variabel bebas terhadap variabel terikatnya. 


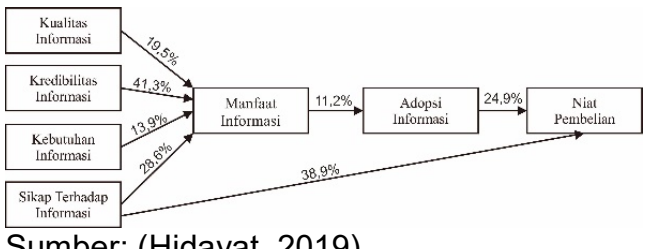

Sumber: (Hidayat, 2019)

Gambar 17. Pengaruh IACM dan Dampaknya Terhadap Niat Pembelian

b. Persamaan Regresi (Uji t)

Uji secara parsial untuk membuktikan pengaruh variabel bebas terhadap variabel terikat digunakan uji t. Dengan membandingkan nilai t hitung dengan $t_{\text {tabel }}$ sebesar 0,191 untuk $\alpha=0,05$ dan jumlah responden 103.

a. Uji $t$ variabel Kualitas Informasi (IQ), Kredibilitas Informasi (IC), Kebutuhan Informasi (NI), Sikap Terhadap Informasi(Al) terhadap Manfaat Informasi (IU)

Langkah-langkah pengujian dalam penelitian ini adalah sebagai berikut:

1. Perumusan Hipotesis Operasional $\left(\mathrm{H}_{0}\right)$ dan Hipotesis Alternatif $\left(\mathrm{H}_{\mathrm{a}}\right)$

$\mathrm{H}_{0}$ : Kualitas Informasi (IQ), Kredibilitas Informasi (IC), Kebutuhan Informasi (NI), Sikap Terhadap Informasi(Al) tidak berpengaruh positif terhadap Manfaat Informasi

$\mathrm{H}_{\mathrm{a}}$ : Kualitas Informasi (IQ), Kredibilitas Informasi (IC), Kebutuhan Informasi (NI), Sikap Terhadap Informasi(Al)) berpengaruh positif terhadap Manfaat Informasi

2. Kriteria penerimaan atau penolakan hipotesis

$\mathrm{H}_{0}$ diterima jika nilai $\mathrm{t}_{\text {hitung }}<0,191$

$\mathrm{H}_{0}$ ditolak jika nilai $\mathrm{t}_{\text {hitung }} \geq 0,191$

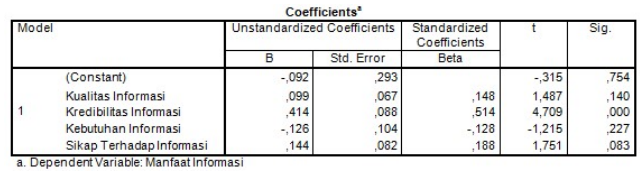

Sumber: (Hidayat, 2019)

Gambar 18. Uji t Pengaruh IQ,IC,NI,AI

Terhadap IU

variabel kualitas informasi (IQ) diperoleh nilai $t$ hitung sebesar $1,487 \geq 0,191$ maka $\mathrm{H}_{0}$ ditolak, variabel kredibilitas informasi (IC) diperoleh nilai $\mathrm{t}$ hitung sebesar $1,709 \geq 0,191$ maka $\mathrm{H}_{0}$ ditolak, variabel sikap terhadap informasi (Al) diperoleh nilai $t$ hitung sebesar $1,751 \geq 0,191$ maka $\mathrm{H}_{0}$ ditolak. Oleh karena itu, disimpulkan bahwa kualitas informasi kredibilitas informasi dan sikap terhadap informasi secara parsial memiliki pengaruh positif signifikan terhadap Manfaat Informasi. Sedangkan untuk variabel kebutuhan informasi (NI) diperoleh nilai $\mathrm{t}$ hitung sebesar $-1,215<0,191$ maka $\mathrm{H}_{0}$ diterima. Oleh karena itu, disimpulkan bahwa kebutuhan informasi secara parsial tidak memiliki pengaruh positif signifikan terhadap Manfaat Informasi.

b. Uji $t$ variabel Manfaat Informasi (IU) terhadap Adopsi Informasi (IA)

Langkah-langkah pengujian dalam penelitian ini adalah sebagai berikut:

1. Perumusan Hipotesis Operasional $\left(\mathrm{H}_{0}\right)$ dan Hipotesis Alternatif $\left(\mathrm{H}_{\mathrm{a}}\right)$

$\mathrm{H}_{0}$ : Manfaat Informasi (IU) tidak berpengaruh positif terhadap Adopsi Informasi

$\mathrm{H}_{\mathrm{a}}$ : Manfaat Informasi (IU) berpengaruh positif terhadap Adopsi Informasi

2. Kriteria penerimaan atau penolakan hipotesis

$\mathrm{H}_{0}$ diterima jika nilai $\mathrm{t}_{\text {hitung }}<0,191$

$\mathrm{H}_{0}$ ditolak jika nilai $\mathrm{t}_{\text {hitung }} \geq 0,191$

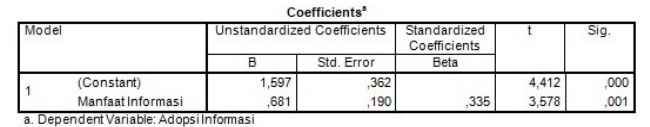

Sumber: (Hidayat, 2019)

Gambar 19. Uji t Pengaruh IU Terhadap IA

variabel manfaat informasi (IU) diperoleh nilai t hitung sebesar $3,578 \geq 0,191$ maka $\mathrm{H}_{0}$ ditolak. Oleh karena itu, disimpulkan bahwa manfaat informasi secara parsial memiliki pengaruh positif signifikan terhadap Adopsi Informasi.

c. Uji t variabel Adopsi Informasi (IA) terhadap Niat Pembelian (PI)

Langkah-langkah pengujian dalam penelitian ini adalah sebagai berikut:

1) Perumusan Hipotesis Operasional $\left(H_{0}\right)$ dan Hipotesis Alternatif $\left(\mathrm{H}_{\mathrm{a}}\right)$

$\mathrm{H}_{0}$ : Adopsi Informasi (IA) tidak berpengaruh positif terhadap Niat Pembelian

$\mathrm{H}_{\mathrm{a}}$ : Adopsi Informasi (IA) berpengaruh positif terhadap Niat Pembelian

2) Kriteria penerimaan atau penolakan hipotesis

$\mathrm{H}_{0}$ diterima jika nilai $\mathrm{t}_{\text {hitung }}<0,191$

$\mathrm{H}_{0}$ ditolak jika nilai $\mathrm{t}_{\text {hitung }} \geq 0,191$

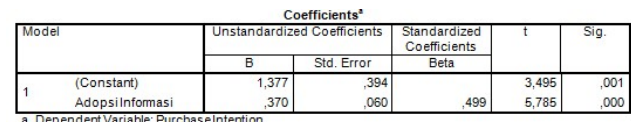

Sumber: (Hidayat, 2019)

Gambar 20. Uji t Pengaruh IA Terhadap PI

untuk variabel adopsi informasi (IA) diperoleh nilai $t$ hitung sebesar 5,785 $\geq 0,191$ maka $\mathrm{H}_{0}$ ditolak. Oleh karena itu, disimpulkan bahwa adopsi informasi secara parsial memiliki pengaruh positif signifikan terhadap Niat Pembelian. 
d. Uji t variabel Sikap Terhadap Informasi (AI) terhadap Niat Pembelian (PI)

Langkah-langkah pengujian dalam penelitian ini adalah sebagai berikut:

1) Perumusan Hipotesis Operasional $\left(H_{0}\right)$ dan Hipotesis Alternatif $\left(\mathrm{H}_{\mathrm{a}}\right)$

$\mathrm{H}_{0}$ : Sikap Terhadap Informasi (AI) tidak berpengaruh positif terhadap Niat Pembelian

$\mathrm{H}_{\mathrm{a}}$ : Sikap Terhadap Informasi (AI) berpengaruh positif terhadap Niat Pembelian

2) Kriteria penerimaan atau penolakan hipotesis

$\mathrm{H}_{0}$ diterima jika nilai $\mathrm{t}_{\text {hitung }}<0,191$

$\mathrm{H}_{0}$ ditolak jika nilai $\mathrm{t}_{\text {hitung }} \geq 0,191$

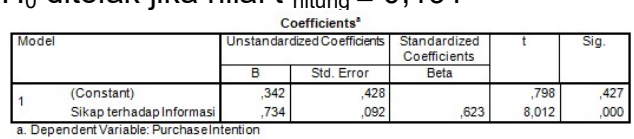

Sumber: (Hidayat, 2019)

Gambar 21. Uji t Pengaruh IA Terhadap P

untuk variabel sikap terhadap informasi (Al) diperoleh nilai $t$ hitung sebesar 8,012 $\geq 0,191$ maka $\mathrm{H}_{0}$ ditolak. Oleh karena itu, disimpulkan bahwa sikap terhadap informasi secara parsial memiliki pengaruh positif signifikan terhadap Niat Pembelian.

\section{c. Uji Signifikansi Stimultan (Uji F)}

Pengujian signifikansi dilakukan untuk mengetahui apakah komponen kualitas informasi, kredibilitas informasi, kebutuhan informasi, dan sikap terhadap informasi berpengaruh secara serentak terhadap kebutuhan informasi. Dengan membandingkan nilai $F_{\text {hitung }}$ dengan $F_{\text {tabel }}$ sebesar 2,48 untuk $\alpha=$ 0,05 , jumlah responden 103, dan jumlah variabel bebas 4 , dapat digunakan untuk menyimpulkan menolak atau menerima hipotesis.

1) Perumusan Hipotesis Operasional $\left(\mathrm{H}_{0}\right)$ dan Hipotesis Alternatif $\left(\mathrm{H}_{\mathrm{a}}\right)$

$\mathrm{H}_{0}$ : Kualitas Informasi, Kredibilitas Informasi, Kebutuhan Informasi, dan Sikap Terhadap Informasi tidak berpengaruh secara serentak terhadap Manfaat Informasi

$\mathrm{H}_{\mathrm{a}}$ : Kualitas Informasi, Kredibilitas Informasi, Kebutuhan Informasi, dan Sikap Terhadap Informasi berpengaruh secara serentak terhadap Manfaat Informasi

2) Kriteria penerimaan atau penolakan hipotesis

$\mathrm{H}_{0}$ diterima jika nilai $\mathrm{F}_{\text {hitung }}<2,48$

$\mathrm{H}_{0}$ ditolak jika nilai $\mathrm{F}_{\text {hitung }} \geq 2,48$

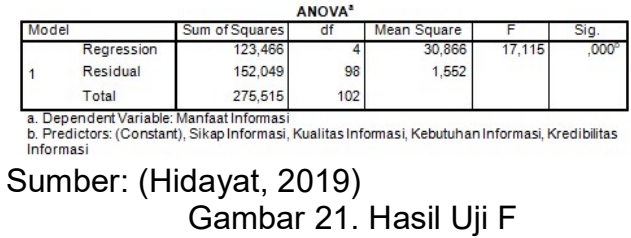

untuk variabel Manfaat Informasi diperoleh nilai $F_{\text {hitung }}$ sebesar $17,115 \geq 2,48$ maka $\mathrm{H}_{0}$ ditolak. Oleh karena itu, disimpulkan bahwa Kualitas Informasi, Kredibilitas Informasi, Kebutuhan Informasi, dan Sikap Terhadap Informasi berpengaruh secara serentak terhadap Manfaat Informasi.

\section{KESIMPULAN}

Berdasarkan hasil pembahasan maka dapat disimpulkan analisis variabel kualitas informasi sebesar 1.806 dengan tingkat persentase $75,2 \%$ dalam kategori baik, variabel kredibilitas informasi sebesar 1.303 dengan tingkat persentase $72,3 \%$ dalam kategori baik, variabel kebutuhan informasi sebesar 836 dengan tingkat persentase $69,6 \%$ dalam kategori baik, dan variabel sikap terhadap informasi sebesar 1.341 dengan tingkat persentase $74,5 \%$ dalam kategori baik. Berdasarkan hasil analisis interprestasi masingmasing variabel menunjukkan bahwa konsumen menggunakan informasi pada komentar Instagram online shopping sudah baik. Selain itu analisis skor variabel Manfaat Informasi sebesar 763 dengan tingkat persentase $63,5 \%$ dalam kategori baik. Hal ini menunjukkan bahwa komentar di Instagram online shopping digunakan sebagai media EWOM sudah baik. Selanjutnyal analisis skor variabel Adopsi Informasi sebesar 1.688 dengan tingkat persentase $70,3 \%$ dalam kategori baik. Hal ini menunjukkan bahwa konsumen pada Instagram online shopping menggunakan informasi pada komentar berdasarkan adopsi informasi sudah baik. Terakhir analisis skor variabel Niat Pembelian sebesar 1.093 dengan tingkat persentase $60,7 \%$ dalam kategori cukup baik. Hal ini menunjukkan bahwa responden memiliki niat pembelian di Instagram online shopping cukup baik.

Berdasarkan analisis regresi menunjukkan bahwa kualitas informasi, kredibilitas informasi, dan sikap terhadap informasi secara parsial berpengaruh positif signifikan terhadap manfaat informasi di Instagram online shopping. Hal tersebut dibuktikan dengan nilai $t{ }_{\text {hitung }} \geq 0,191$. Akan tetapi untuk variabel kebutuhan informasi secara parsial tidak berpengaruh positif signifikan terhadap manfaat informasi di Instagram online shopping, yang ditunjukkan dengan nilai $t$ hitung $<0,191$. Pada analisis 
regresi menunjukkan bahwa kualitas informasi, kredibilitas informasi, kebutuhan informasi, dan sikap terhadap informasi secara serentak berpengaruh terhadap manfaat informasi. Hal tersebut dibuktikan dengan nilai $F_{\text {hitung }} \geq 2,48$. Sedangkan analisis regresi menunjukkan bahwa manfaat informasi secara parsial berpengaruh positif signifikan terhadap adopsi informasi di Instagram online shopping. Hal tersebut dibuktikan dengan nilai $t_{\text {hitung }} \geq 0,191$. Analisis regresi menunjukkan bahwa adopsi informasi secara parsial berpengaruh positif signifikan terhadap niat pembelian di Instagram online shopping. Hal tersebut dibuktikan bahwa nilai $\mathrm{t}$ hitung $\geq 0,191$. Analisis regresi menunjukkan bahwa sikap terhadap informasi informasi secara parsial berpengaruh positif signifikan terhadap niat pembelian di Instagram online shopping. Hal tersebut dibuktikan bahwa nilai $\mathrm{t}_{\text {hitung }} \geq 0,191$.

\section{REFERENSI}

Bataineh, A. Q. (2015). The Impact of Perceived e-WOM on Purchase Intention: The Mediating Role of Corporate Image. International Journal of Marketing Studies, $7(1)$, 126-137. https://doi.org/10.5539/ijms.v7n1p126
Erkan, I., \& Evans, C. (2016). Article: Computers in Human Behavior The in $\mathrm{fl}$ uence of eWOM in social media on consumers 'purchase intentions: An extended approach to information adoption. Computers in Human Behavior, 61(March), 1-8.

Iswara, D. (2016). Pengaruh Kepercayaan, Kemudahan, Kualitas Informasi, Dan Persepsi Risiko Terhadap Keputusan Pembelian. 62(1), 27-40.

Kuspriyono, T., \& Nurelasari, E. (2018). Pengaruh Social Media Marketing Terhadap Customer Bonding dan Purchase to Intention. Cakrawala, 18(2). doi: https://doi.org/10.31294/jc.v18i2

Retnowati, N. (2017). Pengaruh E-Wom ( Electronic Word of Mouth ) Pada Situs Social Commerce Terhadap Niat Beli Generasi X, Y Dan Z.

Wahyunanda, K. P. (2018). Riset Ungkap Pola Pemakaian Medsos Orang indonesia. Www.Tekno.Kompas. Com/Read/2018/03/ 01/10340027/Riset-Ungkap-PolaPemakaian-Medsos-Orang-Indonesia. www.tekno.kompas.com/read/2018/03/01/ 10340027/riset-ungkap-pola-pemakaianmedsos-orang-indonesia. 